\title{
The Limits and Possibilities of History: How a Wider, Deeper, and More Engaged Understanding of Business History Can Foster Innovative Thinking
}

\author{
STEPHEN CUMMINGS \\ TODD BRIDGMAN
}

Victoria University of Wellington, New Zealand

\begin{abstract}
Calls for greater diversity in management research, education, and practice have increased in recent years, driven by a sense of fairness and ethical responsibility, but also because research shows that greater diversity of inputs into management processes can lead to greater innovation. But how can greater diversity of thought be encouraged when educating management students beyond the advocacy of affirmative action and relating the research on the link between multiplicity and creativity? One way is to think again about how we introduce the subject. Introductory textbooks often begin by relaying the history of management. What is presented is a very limited monocultural and linear view of how management emerged. This article highlights how this history may limit the view of management scholars in contrast to the broader perspectives that the histories of other comparable fields, like medicine and architecture, encourage. We discuss how a wider, deeper, and more engaged understanding of management history can foster thinking differently in our field.
\end{abstract}

In 2005, Kirkman and Law's review in Academy of Management Journal hailed a "real internationalization of AMJ" (2005: 385). Such diversity, and the insights that this would bring, led them and others to proclaim the start of the 21 st century as a "golden age of international management research" (Kirkman \& Law, 2005: 379; see also Ellis \& Zhan, 2011).

Tempering this optimism, however, has been the observation that while international diversity has grown, mirroring the internationalization of membership of the Academy of Management, there is a homogenizing use of a Western research paradigm, "whereby researchers inadvertently depress the development of novel ideas and theories that

We would like to thank our researchers at Victoria University for assisting us on this project: Katherine Given, Eve Stacey and Phoebe Smith. may prove to be useful in advancing knowledge in different national and emerging-economy contexts" (Tsui, 2007: 1354). In other words, although knowledge development may appear more diverse, this surface diversity may in fact mask more subtle homogenizing tendencies (e.g., Bruton, Fried, \& Manigart, 2005; Metz \& Harzing, 2009; Meyer, 2006; Terjesen, Hessels, \& Li, 2013).

Similarly, our research into papers presented at the recently held first Academy of Management conference in Africa (with on aim to "bring Africa's unique capabilities and needs to the attention of the world's organization and management scholars," Academy of Management, 2013), found that while a large proportion of the presentations focused on African subject matter, they applied research techniques and theories developed in the West or did comparison studies between modern African 
thinking and practice and what had been found on similar dimensions in modern Western sites. Not one of the 99 presentations took as its primary focus indigenous African organizational forms or management practices, and only one explicitly questioned the appropriateness of conventional theoretical foundations applied in on Africon setting and sought to advance an innovative perspective out of this (Mangaliso \& Lewis, 2013).

Although the AoM in Africa was certainly a step in the right direction with regard to increasing the diversity of perspectives applied to management, we, like Tsui (and others, e.g., Decker, 2013; Li, 2012; Sundararajan, 2014; Welch, Piekkari, Plakoyiannaki, \& Paavilainen-Mantymaki, 2011) encourage management scholars and educators to take different contexts seriously, to develop innovative theory, and to ask novel questions inspired by a deeper contextualization.

These calls for greater diversity are now leveled not just in the interests of fairness and redressing the wrongs done to previously underrepresented groups or cultures, but also because of increasing awareness about the links between greater diversity in groups leading to more innovation, idea generation, and problem solving. One of the first scholarly books on creativity, Arthur Koestler's (1970) The Act of Creation, links creativity to the Latin verb "cogito" (to think), which, he explains, "means to 'shake together'... the creative act, by connecting previously unrelated dimensions of experience is an act of liberation [and] defeat[er] of habit" (Koestler, 1970: 96). In recent times interest in this idea has grown. A range of popular books have appeared trumpeting everything from the "Medici Effect," or the Medici's ability to bring together leaders in a range of disciplines (Johansson, 2006) to how a diversity of "visions" contributed to the creation of the American Constitution (Ellis, 2012); Einstein's breadth of life experiences (White \& Gribbin, 2005); and the range of personalities that Edison assembled (in addition to his own peculiarities) at Menlo Park (Baldwin, 1996). In addition, more scholorly research has linked diversity of perspective as a means of countering the effects of "dominant logic" and spurring creativity and innovation in leading management journals (e.g., Bettis \& Prahalad, 1986, 1995; Jackson, Joshi, \& Erhardtl, 2003; Kearney \& Gebert, 2009; Polanyi, 1981; Shin \& Zhou, 2007; Williams \& O' Reilly, 1998). Others have linked a reducing range of citations, a focus on recent articles, and a faster forgetting of works from earlier ages, to a narrowing of scholarship and a reduction in significant new knowledge development (Evans, 2008; Parolo, Pan, Ghosh, Huberman, Kaski, \& Fortunato, 2015).

We advocate an approach that may seem contrary to conventional thinking, but which could promote deeper and more varied contextualization and, consequently, more innovative thinking: that promoting greater historical engagement could foster greater innovative thinking among management students in the present and management scholars in the future.

This view differs from those reasons put forward by scholars recently as to why we may have seen a decline of substantially new ideas in management studies. They have suggested a range of more obvious limits. For example, a low risk inductivedeductive approach to copying "best practice" rather than aiming abductively for next practice (Martin, 2009; Nattermann, 2000; Prahalad \& Ramaswamy, 2004); theorizing in ways disconnected from the realities of management practice (Clark \& Wright, 2009; Cornelissen \& Floyd, 2009; Sandberg \& Tsoukas, 201 1; Smith \& Lewis, 2011); a desire to borrow theories from other fields rather than develop unique ones (Oswick, Fleming, \& Honlon, 2011; Whetten, Felin, \& King, 2009); professional norms that privilege research appealing to traditional conventions and highly ranked forums (Alvesson \& Sandberg, 2011, 2012; Bartunek, Rynes, \& Ireland, 2006; Grey, 2010; Shepherd \& Sutcliffe, 2011); and the limiting institutional conditions of theory development in business schools (Alvesson \& Sandberg, 2012; Clark \& Wright, 2009; Grey, 2010).

Although history has occasionally been noted in debates about the dearth of innovation, the view that looking forward is the source of new ideas is still promoted: "[W]e still look to the 'founding fathers' for our fundamental questions and our methods for answering them. We carry the historical baggage of their underlying assumptions. And, like lost colonial outposts, we retain a sentimental attachment to the tools, constructs and limitations of our core disciplines" (Suddaby, Hardy, \& Huy, 2011: 237). The impression is that if management is able to escope from its history, thinking will be freed to be more in keeping with new times and to be more innovative.

We believe that engagement with greater historical diversity would help address the concerns that Tsui and others raise. In short, we argue that the limited way in which we have recorded and relay our field's past can limit what we focus on in the present, and consequently, bound progression. New 
thinking can result from a deeper, broader, and more engaged connection with history. Just as our colleagues see greater international diversity in current management publishing as a good thing, we argue that greater diversity in terms of what we take to be important from the past is also important for broadening perspectives.

\section{THE LIMITS OF WHAT IS PASSED ON AS THE HISTORY OF MANAGEMENT}

Introductory textbooks play an essential role in codifying and disseminating the foundations and limits of a field (Kuhn, 1970; Stambaugh \& Trank, 2010). And given that many management scholars only encounter the history of the general field (as opposed to that of their specialization), in introductory courses and texts, management textbooks may provide the best insight into the conventional view of management's origins (Jones \& Khanna, 2006; Payne, Youngcourt, \& Watrous, 2006; Smith, 2007; Van Fleet \& Wren, 2005).

Although management textbooks vary in many respects (Stambaugh \& Trank, 2010), the content of their descriptions of their field's history and the process by which it is outlined is strikingly similar. A simple "potted history" may be found in most introductory texts. These narratives typically identify the key kernel as the assertion of a mechanisticindustrial worldview (if cultures prior to the Industrial Revolution are incorporated it is because modern management's staples-planning, directing, organizing, controlling-are discerned in their achievements, not because they looked at management differently; Tsoukas \& Cummings, 1997). Management's origins are almost always outlined in "chapter 2" after an introductory chapter. This forms a basis upon which management's more recent ideas are presented in the chapters that follow. They are presented as the foundations upon which the subject has built and responded to. Table l outlines this unanimity among best-selling management textbooks.

The idea that management and business students are introduced to the most cursory, monocultural (i.e., Anglo-American) and linear versions of history (e.g., the Industrial Revolution, U.S. railroad companies, F.W. Taylor, Weber, Drucker...) has been noted (Jones \& Khanna, 2006; Smith, 2007; Van Fleet \& Wren, 2005). Relatedly, the way in which homogeneous historical narratives can limit critical and creative thought has been written about in detail, particularly by French historian Michel Foucault (1985), whose studies show how traditional histories legitimate the establishment and discourage alternatives. Foucault's ideas in this regard have been applied to critiques of specific limitations in management thinking with regard to bureaucracy (Cummings \& Bridgman, 2011); crisis management (Vanderbroeck, 2012); and project management (Söderlund \& Lenfle, 2013). But nobody has really investigated where these foundational limits

TABLE 1

Key Points of Management's Origin Narrative in Textbooks

\begin{tabular}{|c|c|c|c|c|}
\hline Textbook & Placement & $\begin{array}{c}\text { Primary } \\
\text { individual }\end{array}$ & Precedents/continuation of & References \\
\hline Rue \& Byars (2009) & Chapter 2 & Taylor & $\begin{array}{l}\text { Rapid industrialization but production } \\
\text { methods crude, need to be improved }\end{array}$ & $\begin{array}{l}\text { Chandler (1959); Mee (1963); } \\
\text { Taylor (1903, 1911); Wren } \\
\text { (1972, 1979); Wrege \& } \\
\text { Hodgetts (2000) }\end{array}$ \\
\hline Kinicki \& Williams (2009) & Chapter 2 & Taylor & $\begin{array}{l}\text { Industrial expansion, labor } \\
\text { in short supply, need to improve } \\
\text { labor productivity }\end{array}$ & None \\
\hline $\begin{array}{l}\text { Robbins, Bergman, Stagg, } \\
\text { Coulter (2012) }\end{array}$ & Chapter 2 & Taylor & $\begin{array}{l}\text { Popularity of division of } \\
\text { labor, industrial revolution, } \\
\text { need to maximize } \\
\text { efficiency }\end{array}$ & $\begin{array}{l}\text { Banta (1993); George (1972); } \\
\text { Kanigel (1997); Taylor (1911); } \\
\text { Wagner-Tsukamoto (2007) }\end{array}$ \\
\hline Schermerhorn et al. (2014) & Chapter 2 & Taylor & $\begin{array}{l}\text { Workers produced less } \\
\text { than they were capable of because of } \\
\text { inefficient work methods }\end{array}$ & $\begin{array}{l}\text { Kanigel (1997); Locke (1982); } \\
\text { Taylor (1911), Wrege \& Perroni } \\
\text { (1974); Wren (2005) }\end{array}$ \\
\hline
\end{tabular}


emerged from, the extent of this homogeneity relative to other similar fields, or reflected upon how this may impact on innovation and creativity in the field. We seek to do this in the remainder of our article.

\section{The Origin of the Origins}

As Table 1 illustrates, the references provided for the histories passed on to management initiates in textbooks are generally few in number. They tend to be the few management history books that were written at the time most of these books' first editions were developed (the 1970s), particularly those books written by C. S. George and Daniel Wren. Sometimes academic articles are also cited, either from business history journals or in other journals, but with a historical theme. Wren's books, in particular, cited academic journal research as a basis. There was a convergence of interests here. The post-World War II period witnessed the spread of business schools at universities, where the first serious histories of management were written that outlined the field's noble origins and helped legitimate them as "university worthy." The Ford and Carnegie reports outlined the legitimate form of a business school and its curricula, and with a further growth spurt in student numbers and advances in pedagogy and publishing, the first textbooks (as we know them) emerged en masse.

As a starting point in investigating the idea that management and business history lacks diversity, we sought a preliminary snapshot of what management and business historians saw as worthy of investigation. We surveyed the most highly regarded journals of management and business history to ascertain the geographical locations that they focused on. We coded the 859 articles from the journal Business History published between 1950 and 2010; 894 from the journal Business History Review for the same period; and the 234 and 78, respectively, published in the more recently established Journal of Management History and Management and Organization History. About $80 \%$ of the articles could be coded for geographic focus, and we sent the results to www.worldmapper.org to create a map that depicted the world in terms of the relativities in the data. The world according to the history of management and business is shown in Figure l. Two Anglo giants dominate. Japan, Australia, New Zealand, and South Africa just about hold their own, while the rest of Africa, Asia and South America shrink to slivers.

However, on viewing this picture we did wonder, were we unreasonably harsh on the reporting of management and business history? Would it not be the case that historians writing in English and contributing to leading scholarly journals (given that highly rated journals tend to be based in places such as the U.S. and the U.K.) would be similarly predisposed to focus on "their own?" Might it not be selfevident that management and business histories should focus on the regions where the Industrial

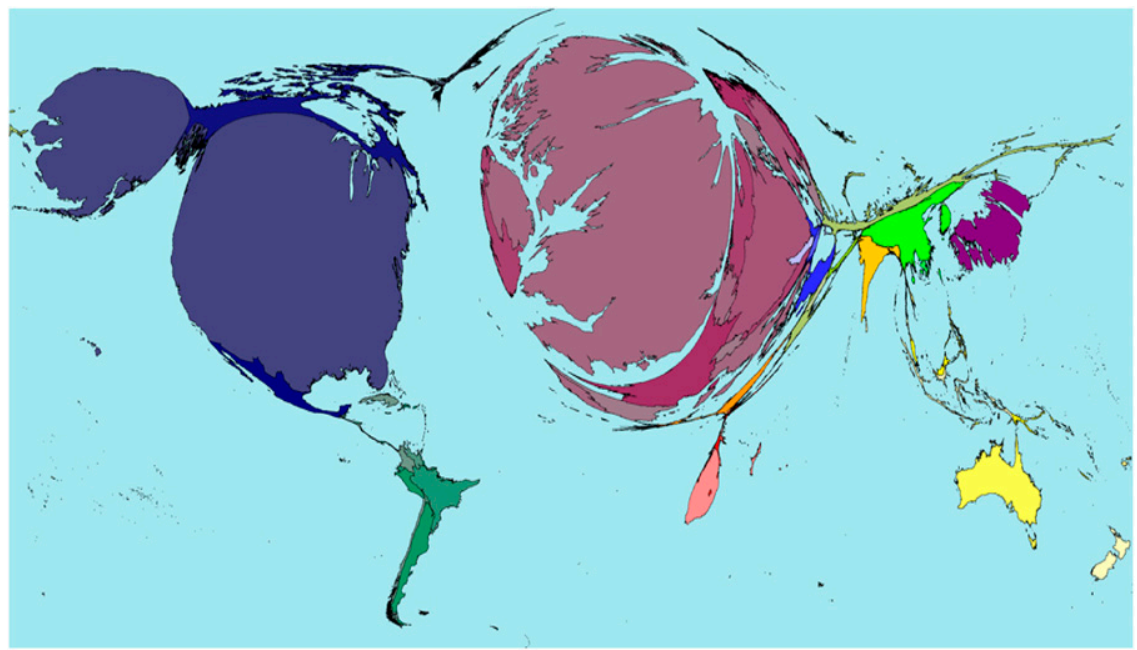

FIGURE 1

The World According to Management and Business History Journals. The authors wish to thank Benjamin D. Hennig and Danny Dorling at the University of Sheffield and www.worldmapper.org for kindly developing this map based on our data. 
Revolution or management consulting began? The Worldmapper result made us curious to investigate further.

We set out to probe the nature of management and business history writing by selecting reasonable comparisons to analyze whether management history writing was any more limited than other types of history and whether there had been any changes of scope over a substantial period of time. We already knew that business had two highly regarded history journals that been published for over 6 decades: one based in in the United States, one in the United Kingdom (Business History and Business History Review). Having decided it would be useful to use these journals as representative of the field and leave aside the other two management history journals, which were established far more recently, we required as comparable sets disciplines with more than one highly rated history journal devoted solely to the study of just its history (i.e., journals with a broader focus on the history of a group of subjects like science or art were not useful for our purposes) and for one of these journals to be based in the United States and another in the United Kingdom or another country.

Economic history, law, philosophy, and many others fell short of our comparable academic journal criterion for selecting comparator fields. However, the history of medicine and the history of architecture did meet our criteria. Like management and business, these are not normal sciences or, indeed, normal arts. They are stochastic professions where, while we may be guided by theories or principles, we must adjust our thinking and recalibrate our actions as our subjects or cases or stakeholders respond in individual ways to previous interventions in changing environments. Our initial investigations also revealed that there seemed to be no recent laments in these fields about the lack of new ideas. Consequently, we sought to analyze and contrast what their histories recorded with management and business history.

We constructed three sets of abstracts dating from 1951 to 2010. The business history set contained all 859 abstracts from articles published across this period in the U.K.-based Business History, and the 894 abstracts published in Business History Review. (The Journal of Management History and the Journal of Management and Organizational History data, from which we shall refer to on occasion below, are based in the United States and the United Kingdom, respectively). The medical history set was made up of 602 from the U.K.-based Journal of the History of Medicine and Allied Sciences and 1554 from the U.S.-based Bulletin of the History of Medicine. The third set, of architectural history abstracts, comprised 1059 abstracts from the U.S.-based Journal of the Society of Architectural Historians and 292 from the U.K.-based Construction History. Although neither the medical or architectural set contained the abstracts of all the articles published in this period (we were reliant on downloading electronic versions of abstracts, and a few years were not obtainable in both the medical and architectural history journals, generally when there was a change of publisher), in both sets we were able to gather the majority of all abstracts with representative samples across all 6 decades of our survey.

After discussing and ruling out potential criteria (such as whether the perspective applied was conventional or unconventional) for being too difficult to determine reliably in our large data sets, we settled on two simple aspects: the geographical location focused upon in the article, or "place" and the temporal setting or age focused

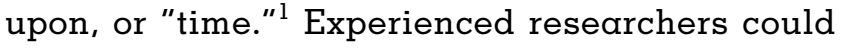
quickly code for these aspects with extremely high inter-rater reliability, and given that our purpose was not to capture the truth of what happened in the past but to seek comparison that would help to raise questions about how what we focus on in the past illuminates pathways in the present, time and place were effective dimensions with which to begin.

As we explain in the paragraphs to follow, we found that management and business history has a far more limited geographical and temporal perspective than either of its two comparator fields of inquiry. More encouragingly, we found signs that greater diversity in management and business history is certainly possible and that it may now be emerging. And beyond the presentation of our data, we argue that the potential relationship between greater diversity of historical perspectives and innovation has important implications for reenergizing current management research and education with new ideas developed from within the field.

\footnotetext{
${ }^{1}$ When an article focused on two or more discrete geographical locations, we gave each location a fraction of one (e.g., a focus on the U.S. and Japan scored .5 for each location). When an article focused on a very broad swathe of time, we recorded the median point.
} 


\section{Relative Limits?}

The following three subsections report our results for geographic place, time, and time and place combined. The Appendix provides a table that shows the number and percentage of abstracts from each set that were able to be coded for time, place, and both time and place.

\section{Place}

Our initial analysis on the places focused upon indicated a far greater deal of geographical variety in journals of architecture and medical history. Just over a quarter of all business history papers focused on territories beyond the United States and United Kingdom (Fig. 2). Although the United States and United Kingdom, respective home bases for the two journals chosen to represent each of these professions, were also the two most written about national settings, nearly half of the articles on architectural history were written about other locations, as were over a third of the medical history papers.

Moreover, there is a significant difference in the total number of countries focused upon in that "other" category. A total of 84 countries have been afforded at least some consideration by architectural historians: 80 in medicine and only 50 in business. No other country has over $5 \%$ representation in business history journals. In medicine and architecture two other country sets achieve this level of significance (Germany and France, and Italy and France, respectively). While we might hope that the more recently published management history journals would demonstrate greater diversity and variability of place, the results here are fairly consistent with their business history cousins as Figure 3 illustrates.

When we grouped the data into 6 decades, from the 1950s to the 2000s, for Africa, Asia, Continental Europe (i.e., Europe minus the U.K.), North America, and the United Kingdom, we observed some interesting changes in the representation of place over time between the three sets. ${ }^{2}$ Some signs are encouraging, with respect to diversity, in management and business history journals. The percentage of articles relating to Asion and African locations

\footnotetext{
${ }^{2}$ We recognize that grouping our data into continents in this regard is problematic. For example, the stories from Morocco will likely be very different from those of South Africa or Uganda. But our aim here is to illustrate in a powerful way a lack of diversity in management and business history, not to replace global homogeneity with a belief that there should be continental homogeneity.
}

that could be coded for place have increased steadily from around $2 \%$ in the 1950 s to $5 \%$ in the 2000 s for Asia and from $0.75 \%$ to nearly $2 \%$ for Africa. Correspondingly, interest in the United Kingdom has waned.

But what is starker when one compares the data are how the medicine and architecture sets show much more variability in focus over time than does business. For example, architecture history papers go from next to nothing on Asia and Africa in the 1950 s to $16 \%$ and $4.5 \%$ on these regions, respectively, in the 1980s, a peak which drops away again after this flourish. Medical histories' interest in these two locations peaks in the 1990s (at 10\%) and 1960s (4.3\%), respectively. This would appear to indicate that medical and architecture history is more able than business history to shift historical focus so as to move with the problems or interests of the times. This relative lack of variability in business history research is something we will also see with respect to temporality.

\section{Time}

In addition to coding articles for place, we also sought to gain some appreciation of the times or ages focused upon across our three sets of history journals and arranged these into 20 -year blocks. As with place, not all articles were focused in this way, but, the vast majority (about 70\%) were, and could be coded. Whenever a broader period of time was focused upon we recorded the midpoint or median year (so, e.g., if an article focused on events from 1860 to 1890 the date attributed to that article was 1875). We recognize that this in an imperfect form of measurement, but we believe that the numbers of articles coded in this way are high enough to begin to interpret some interesting trends and ask some useful questions.

The bar (or "Manhattan" skyline) charts show the frequency of dates focused on within the journal articles for each of the three discipline sets published during the period 1950-2010 as a percentage of the total. Each has different characteristics. Architecture (Fig. 4) is the most broad ranging, with a very specific homage paid to the period 1900-1920, but significant populations of articles date back through many centuries.

Medical history (shown in Fig. 5) lacks a stand-out skyscraper, but has a widespread focus of over $6 \%$ representation right across the period 1800-1940, and at least $1 \%$ representation all the way back to 1600. 


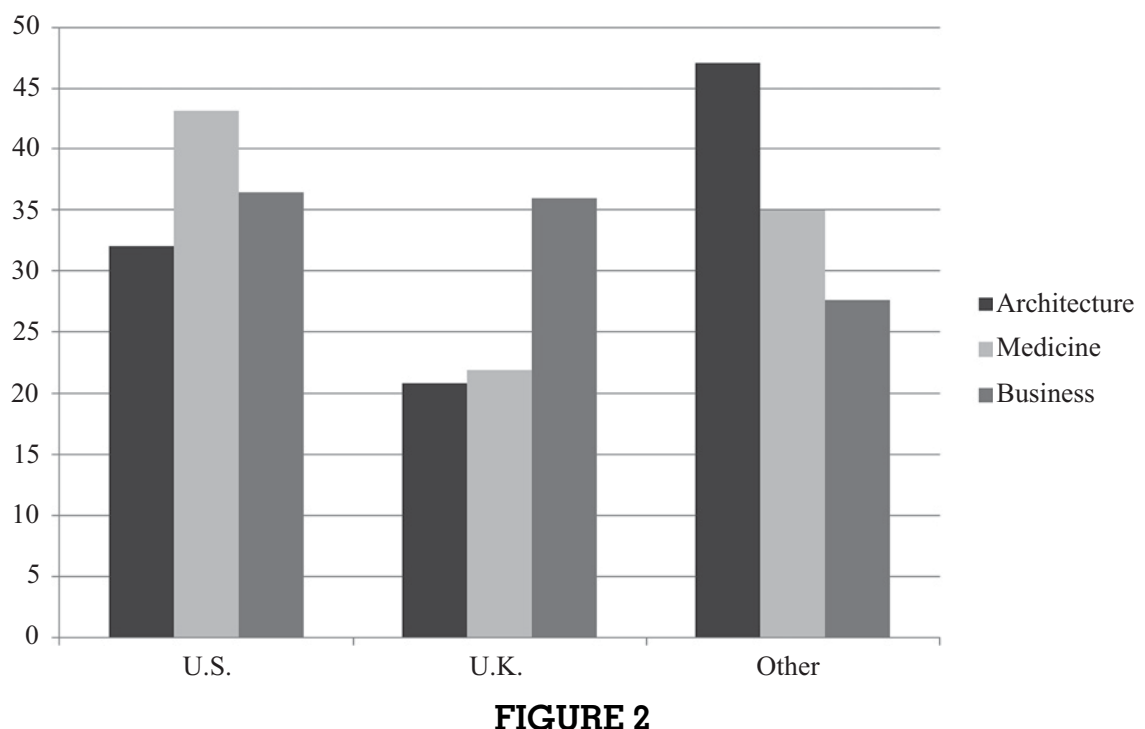

Percentages of Geographical Focus in Architectural, Medical, and Business History Papers

Business history (Fig. 6) is far more piled up toward the right-hand side of the groph, with 1920-1940 matching the height of architecture's tallest bar, but with a range of similarly tall edifices on either side. The periods from 1900 to 1980 in business history each have greater representation than any single period in medical history. If we were hoping that the management history journals were broader in their emphasis, again, as with place, the patterns here are more or less the same, but with a greater intensification of bias toward sites dated 1920-1960 (Fig. 7).

Furthermore, when we look at the average time of focus for each of our three subject sets, what falls within one standard deviation of these averages, and how these numbers change through the decades, we can interpret some interesting differences between business, architecture, and medical history in terms of diversity of focus (see Fig. 8).

The mean date for the 1434 business history articles for which dates could be determined was 1879. For architecture history $(n=731)$ it was 1763 ; for medical history $(n=1308), 1791$. When we removed the dates ascribed to articles that focused on a broad sweep of history (e.g., "the 18th century"), the averages understandably moved forward in time: business $(n=480), 1908$; architecture $(n=326), 1806$; medicine $(n=417), 1843 .{ }^{3}$ Architecture

\footnotetext{
${ }^{3}$ An interesting sidebar is just how much greater the percentage of business history journal articles relate to specific times and places (c. $80 \%$ ), relative to a much lower percentage in architecture and medicine (40-50\%) where the concerns are more often general or time/place neutral (see Appendix).
}

and medicine show more variability of movement of the average time of focus over the decades, with a distinct shift of focus in architecture in the 1970s and medicine in the 2000s, perhaps with an emphasis shaped more by the particular concerns of the times than reinforcing traditional origins or sites of truth. Business has followed a steady path at a consistent distance from the past (about 100 years, or about 70 years if we adjust so as to not include those articles with rather vague dates e.g., the 17th century). However, the leveling off in recent times around a mean date of 1910 would be

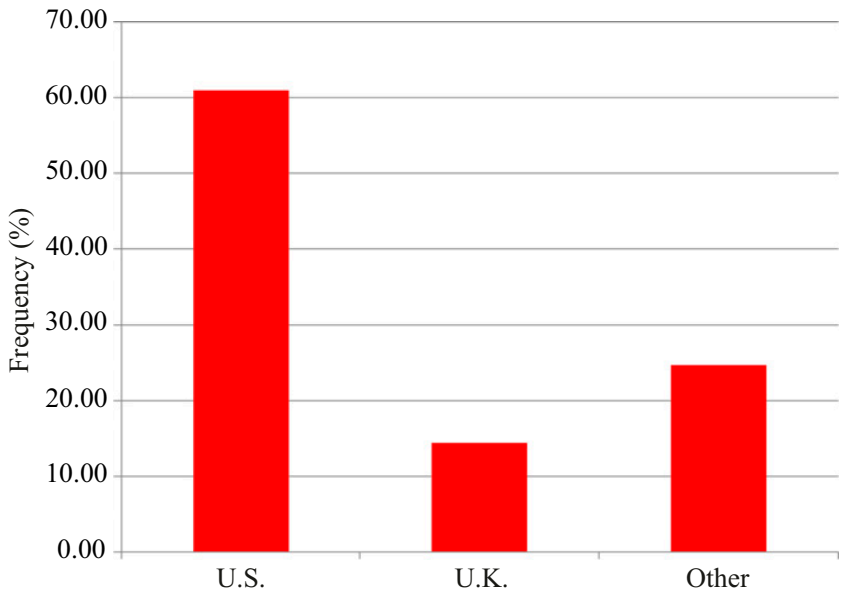

FIGURE 3

Total Percentages of Articles Coded for Place in the History of Management Journal and the Journal of Management and Organizational History 


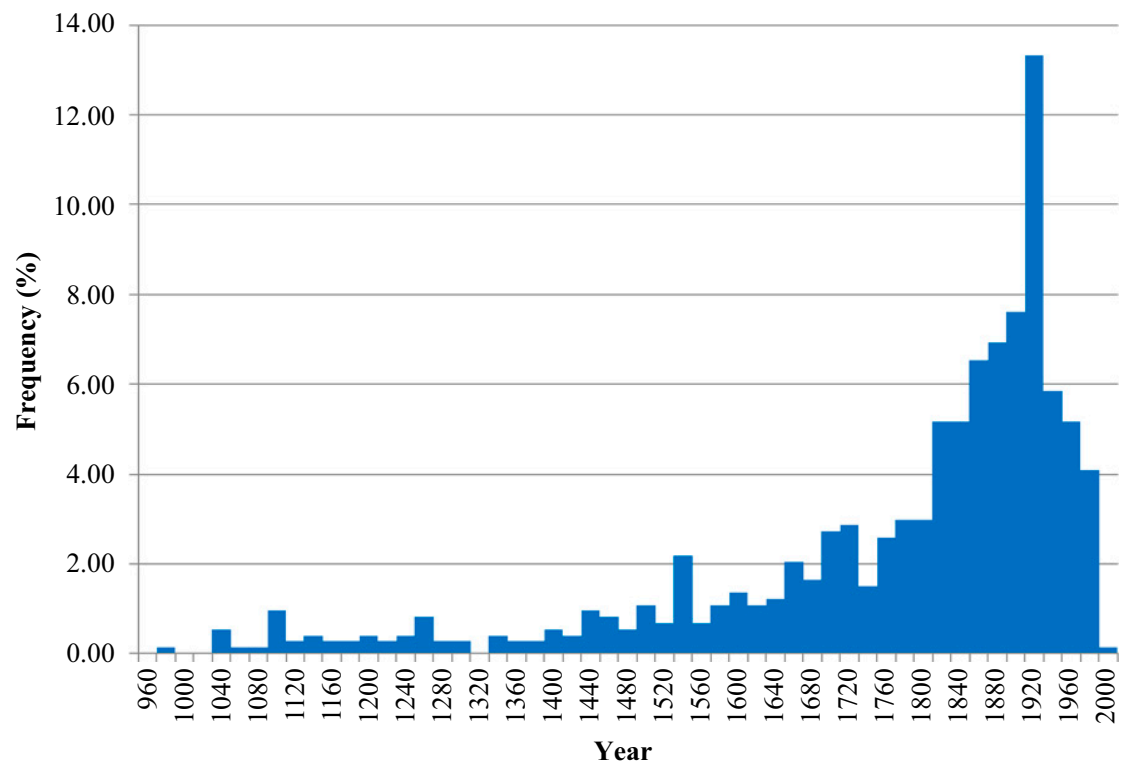

FIGURE 4

Architectural History "Manhattan"

a concern if it suggested a sedimentation and growing stagnation.

More interesting, however, may be the standard deviation results, which may illustrate the normal breadth of focus. Here, the standard deviations around the mean measures were two and a half times larger for medicine and architecture than for business. For business history it was 115 years; architecture 247; medicine 26l. When we removed the dates ascribed to articles that focused on a broad sweep (e.g., 19th century Trade Associations), the standard deviations' differences were even starker: business, 47 years; architecture, 209 years; medicine 157 years. The circle in Figure 8 around the smallest standard deviation relating to business history writing in the 1980s falls in the same period that most of today's major textbooks in management and business

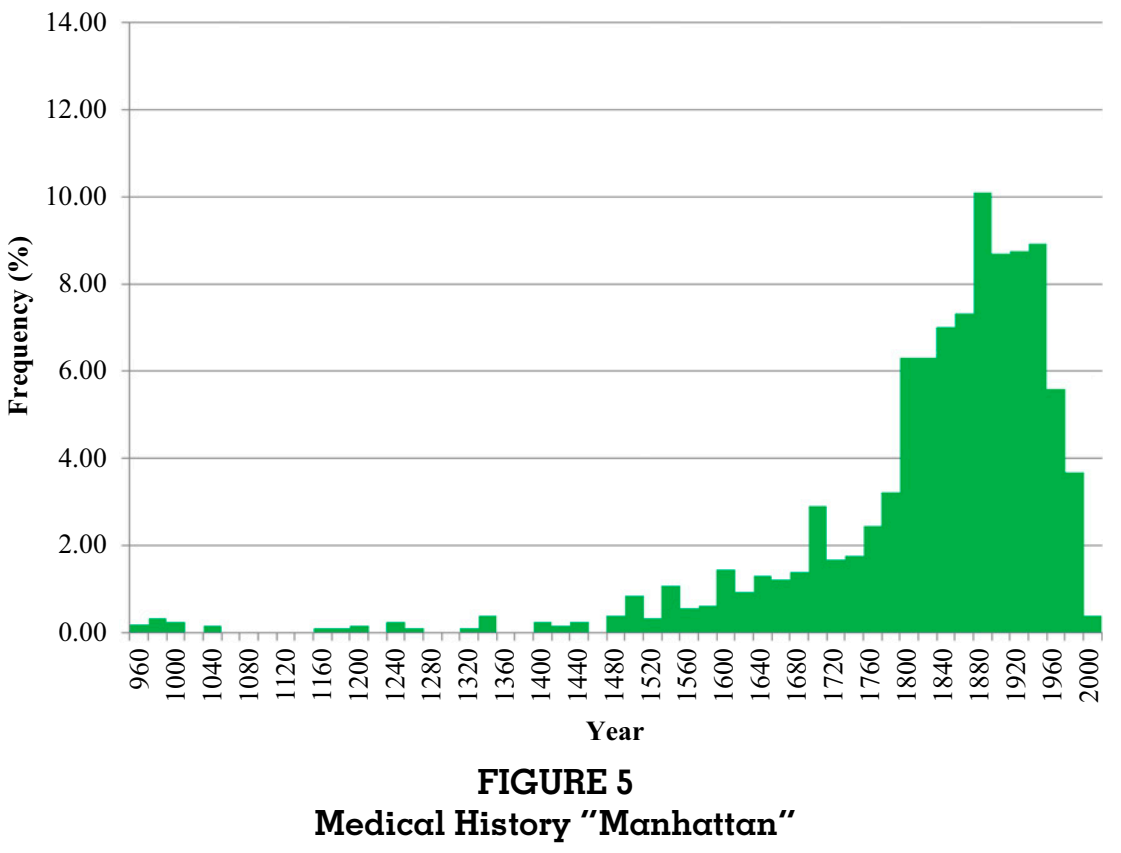




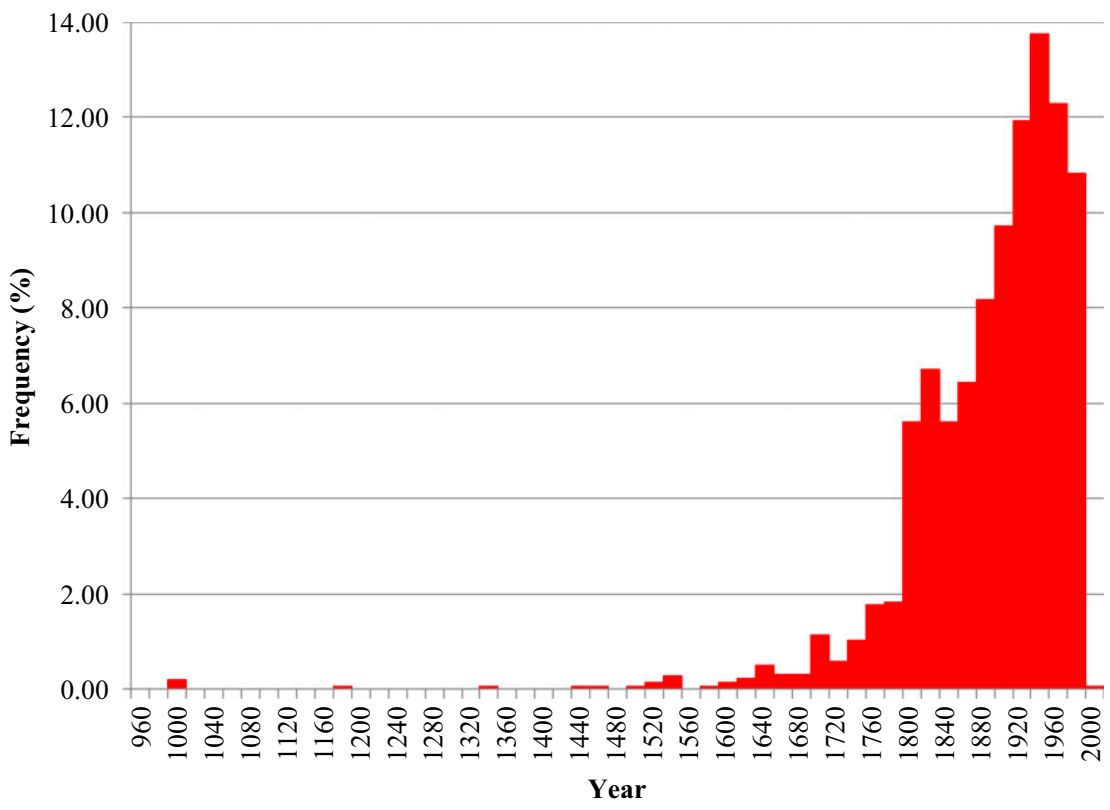

FIGURE 6

Business History "Manhattan"

subjects were developed or consolidating into their current modern forms in the 2nd and 3rd editions. Although these texts were generally informed by books (e.g., George, 1972; Chandler, 1977; Wren 1972), these books and the textbook writers themselves could have been influenced by the narrow view of the field in general in creating the narrow histories that they pass on to students. These textbooks are often now into their 12th, 13th or 14th editions, and nuances may shift to move with the times, but the key characters and events in these histories have not changed.

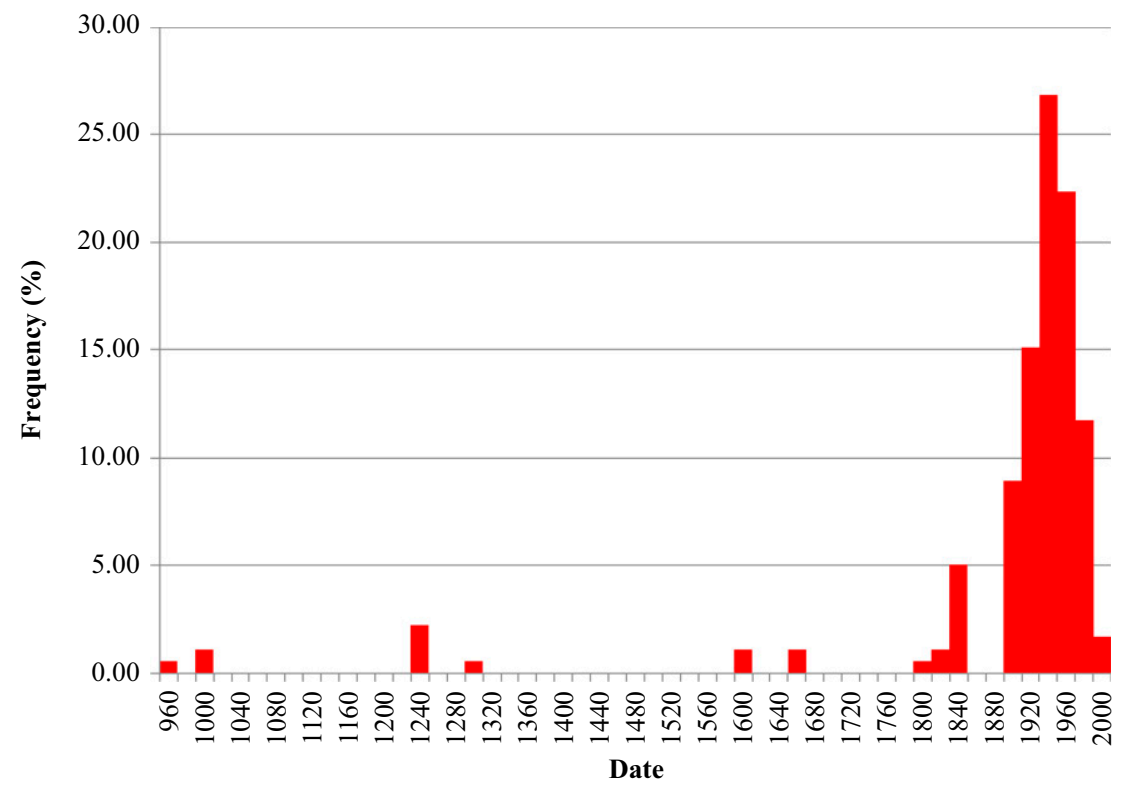

FIGURE 7

Management History "Manhattan" 


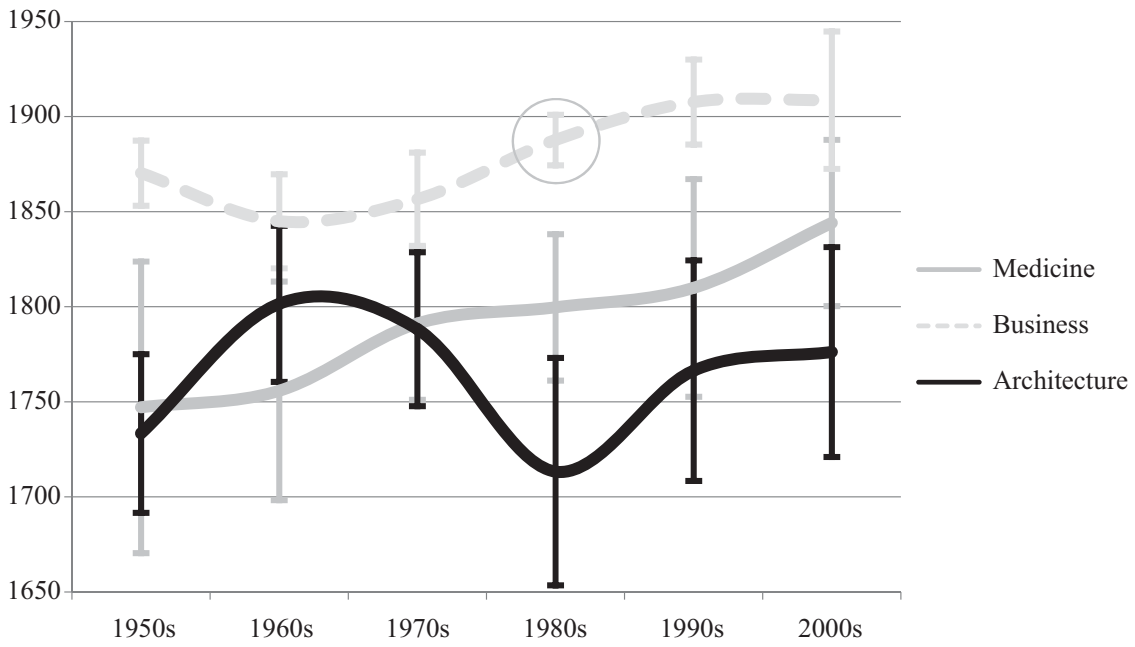

FIGURE 8

Average Date Focused on Within Journals Over the Decades (1950-2010) in Each of Three Disciplines With Bars Representing Single SDs

\section{Time and Place}

Having looked at the data with respect to time and place, we then combined these dimensions, taking those articles that could be coded for both (since 1800 , to enable more readily comparable graphs) and plotting the percentages for each of the three sets in bubble area graphs.

As Figure 9 demonstrates, business is highly concentrated around North America between 1840-1860, and the United Kingdom and North America in the first 60 years of the 20 th century, although it does have representative "dots" of interest on almost all areas of the grid.
Architecture (shown in Fig. 10) has a wider range of interests, geographically and temporally, with more continental European focus and significant pockets of interest outside of the North-Western world (e.g., Africa 1820-1840; South America 1840-1860; Asia 1820-1840).

Medicine (Fig. 11) has a much broader time span of concentrated interest and a greater focus on Continental Europe than management and business history, but it demonstrates a smaller degree of interest beyond those three geographies across time thon architecture. However, like business it does cover more of the "bases" even if only to miniscule degrees in many cases.

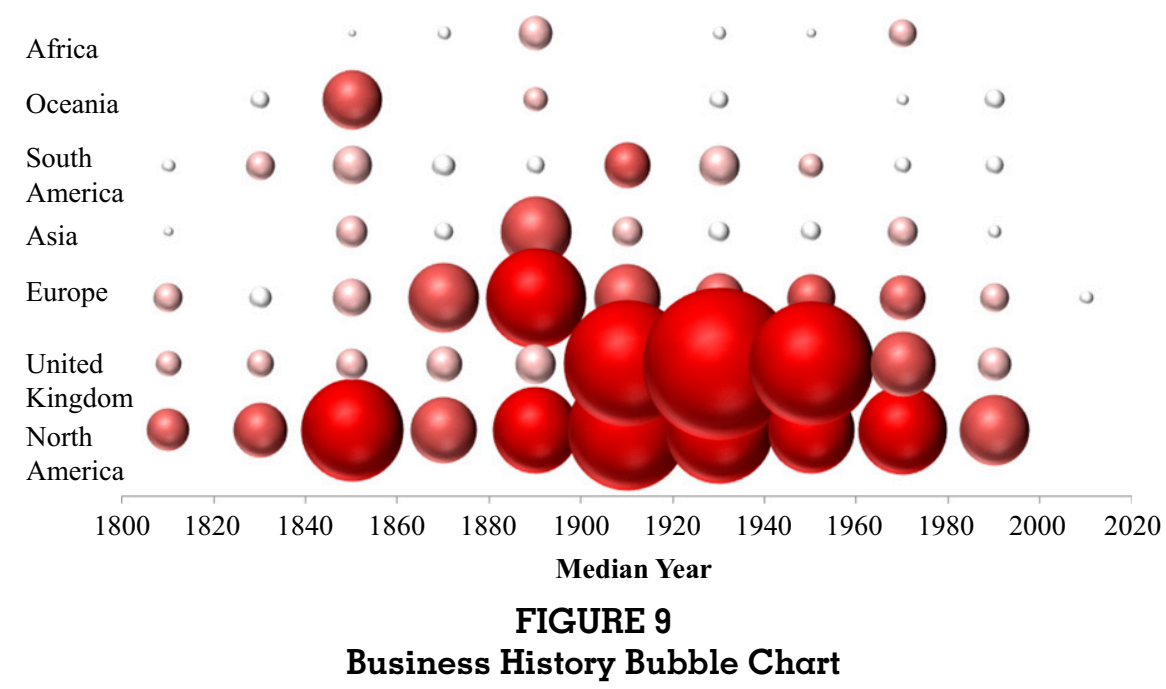




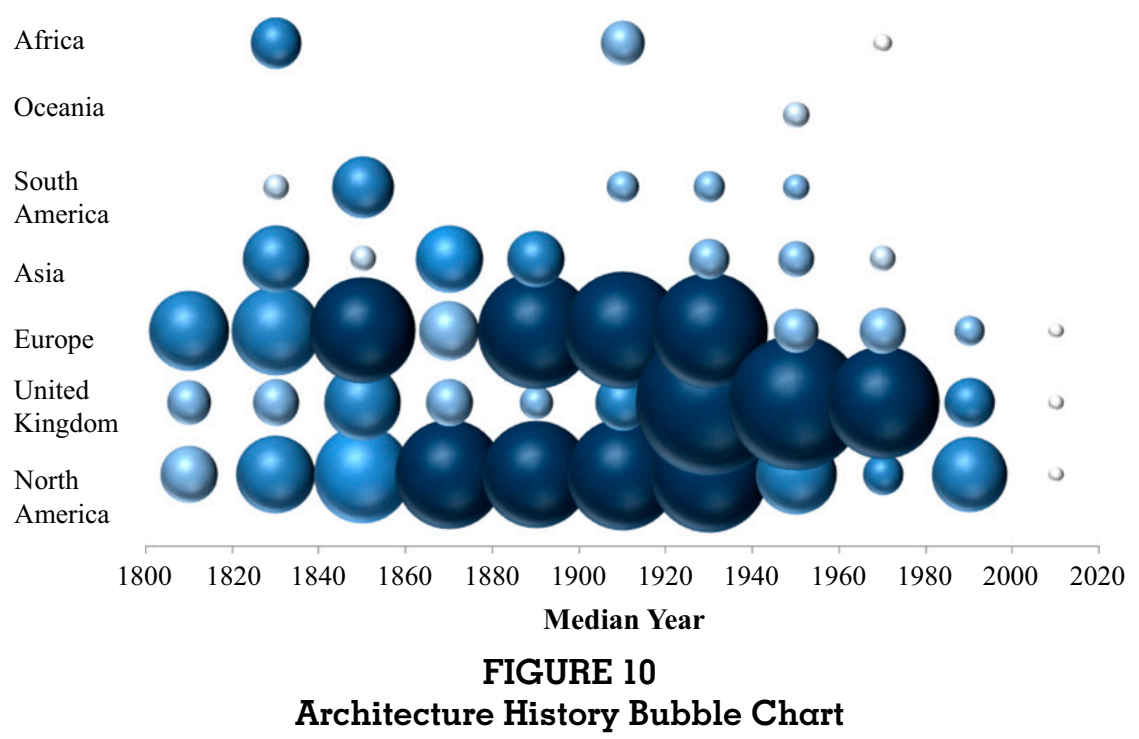

\section{DISCUSSION:}

\section{IMPLICATIONS FOR MANAGEMENT RESEARCH} AND EDUCATION

Early in this article we outlined the premise that greater diversity of perspective can encourage greater innovation, and we linked it to current discussions about why management is not currently generating significant new theories and perspectives. We suggest that $\alpha$ limited view of the past may constrain perspectives of what we take management to be about in the present, and subsequently, could be limiting future development. We then sought to investigate the limits of the proctice of management and business history writing relative to history scholarship in architecture and medicine.
So, how does management and business history compare when looked at in this light? First, the bad news: It has a far more limited geographical and temporal perspective than either of the two comparable fields of inquiry we have investigated here. Based on what we have outlined above, we could surmise that when the history of management and business was first taken seriously, as part of a process to legitimate the then-fledgling field in the mid-20th century (at the same time as other institutionalizing measures, such as the sponsorship of the Ford and Carnegie reports on defining the standard business school curriculum), it embraced origins that helped legitimate and make sense of the present constitution (Gordon \& Howell, 1959; Pierson, 1959; Cummings, 2002;

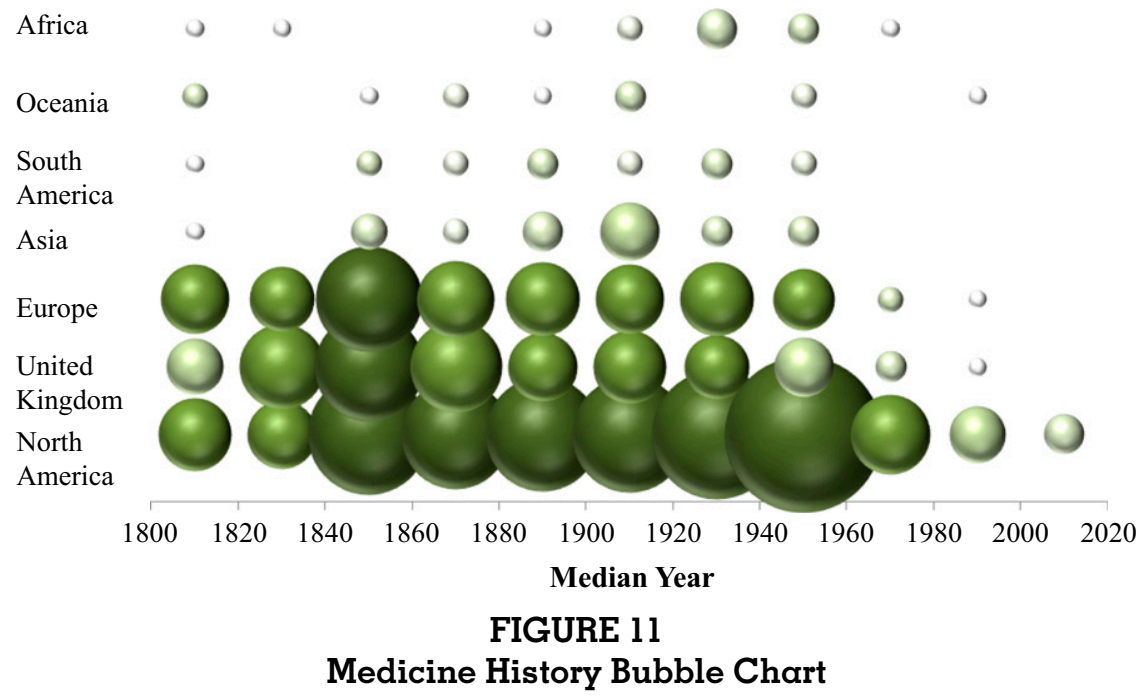


Khurana, 2007). These origins were found in the United States and Britain in the 19th and early 20 th centuries. Since that point, management and business history's temporal focus (unlike architecture or medicine) does not appear to have changed focus to reflect particular problems or new concerns. And, it seems now that it may be anchored on a median spot, 1900-1920, as conventional histories are prone to do, unless they are challenged. The danger is that the "amputated reality" of management history may now be acting as a limiting "map for modern travellers" in our field (Glassie, 1999: 6; Salvemini, 1939: 60). The past may become an archive stuck in time, rather than a vibrant dynamic reflection of a vibrant dynamic field with multiple possibilities.

In reflecting on this, it may be worth considering that there has not been widespread lament in the leading medical and architecture journals asking where their fields' new ideas are. It may be that their wider, more diverse and dynamic histories, and related broader view of what their boundaries could embrace, help to spur creative hybrids and other forms of innovation. However, in defense, readers may already be thinking that architectural historians, for example, would have it easier than business historians in being able to study a wider ronge of physical remains and plans. This is certainly true, but just as "difficulty is the excuse history never accepts" (Murrow, 1961), difficulty should not be an excuse for historians or management scholars. If the intent exists to study difficult or nonobvious objects or look in novel ways and adopt other perspectives, then such histories will emerge.

And this brings us to some good news. Figure 9 indicates that business history may come from any age and location, if we choose to focus there. Specs of interest are widespread and even more so in business than architecture. Furthermore, while the management history "Manhattan" landscape shown in Figure 7 is similar in most respects to its business history counterpart, it does demonstrate pockets of interest prior to 1680 . In addition, while the percentages are small, there are increases in articles focusing on Asia, South America, and Africa.

Although management and business history's collective memory, or perspective of the past, does appear limited when compared to other fields, what we found also points to the possible role that this history can play in broadening thinking in the future. Rather than merely teaching or implying that what is worthy of attention in management and business history happened in the United Kingdom and the United States between 1800 and 1920, we should actively seek out and encourage young scholars to seek out alternative perspectives from other times and places that could be rejuvenated or combined with thinking from other times and places to create interesting hybrids, or broaden our understanding of what the field could be about, or help us to look differently at old and new management issues; that is, new knowledge about history that we hope will be incorporated into textbook histories that can provide new vehicles to the future (Stambaugh \& Trank, 2010).

To help promote this development, we provide three vignettes to illustrate the sort of historical research that would add to this broadening and deepening of perspective and the potential for innovative thinking in management. They relate to going wider than the small set of standard characters outlined in those "chapter $2 \mathrm{~s}$ " and looking into worlds that are not influenced by modern Western industrial perspectives, and going deeper by encouraging an appreciation of other languages and getting more engaged with archives.

\section{Going Wider: Looking at Other Worlds of Management}

Although we do not wish to criticize the AoM African initiative we mentioned earlier in this article (unlike the regular AoM, the African version did not have a particular management history track, so it may not be surprising that few took the perspective that we are advocating here), it would be valuable, we believe, to combine this initiative with a real effort to find interesting underappreciated alternative approaches to management from that continent's-and indeed other underrepresented continents'-pasts. A study that is exemplary in this regard is Avner Greif's work on the coalitions formed by llth century Maghribi traders from North Africa that enabled them to work efficiently across borders without the legal institutions that would regulate what we today would consider a conventional market. As Greif (1993: 526) explains:

Expectations, implicit contractual relations, and a specific information-transmission mechanism constituted the constraints that affected an individual trader's choice of action. In particular, these constraints supported the 
operation of a reputation mechanism that enabled the Maghribis to overcome the commitment problem [and] reinforced the expectations on which the coalition was based, motivated traders to adhere to the implicit contracts, and led to entry and exit barriers which ensured the sustainability of the coalition.

At the time that Greif wrote this, it was customary, following the thinking of Ronald Coase, to distinguish between market and nonmarket institutions (like those which governed the Maghribi's practices). The new forms of markets enabled by recent developments in information technology, forms that are difficult to regulate with conventional legal systems, were not known. Revisiting premodern nonmarket cases like that of the Maghribi may be a useful way to think innovatively about how the current rise of what we call secondary-or after-markets (Bayón, 2013), such as those operated by derivative traders, eBay, Craigslist, Amazon, and Taobao, might selfregulate, evolve, and be enhanced or detracted from through the imposition of conventional market constraints (see Baumol, 1990, for a similarly insightful cross-cultural study of diverse types of entrepreneurship from different ages). ${ }^{4}$

Further examples of how a change in historical perspective could change future practice and scholarship could be the application of medieval, scholastic, and monastic traditions to think differently about business ethics or modern knowledgeintensive firms (McGrath 2005, 2007; Wren, 2000). It had been the case that the history books used in New Zealand schools continued to promote the views of those who had first reported on the wars between the British colonial forces and the indigenous Maori, right up until the 1980s (see, e.g., Oliver, 1981: 58ff). These views were that the Maori had "shewn no strategical knowledge" (Carey 1863: 66) and that they had displayed the "weaknesses generally associated with savage races [fighting] under no definite strategical plan and without unity of command" (Shrimpton \& Mulgan, 1930). It was not until this history was questioned by others that it was discovered that the Maori had actually achieved many victories against difficult odds as a result of

\footnotetext{
${ }^{4}$ An inspirational project that goes wider than conventional norms in this regard is the emerging open-source African Economic History project being developed by Ewout Frankema from Wageningen University and Ellen Hillbom from the University of Lund (see www.aehnetwork.org/textbook/).
}

their "unusual" practices, that Maori approaches (loosely planned but mostly emergent), were acknowledged as worthy of further consideration (Cummings, 2002). A new generation of curious historians were then able to see that "[i]t is true that Maori organization was informal and unstructured. But the absence of European forms of organization does not mean that organization per se was absent" (Belich, 1986: 130). The pride and creative dynamic that these historical reappreciations helped promote are still being felt today. Moreover, this insight would have offered an interesting alternative view on the debates that beset strategic management in the 1990s, as to whether strategy was more truly about planning from the top or bottom-up emergence (Ansoff, 1991; Mintzberg, 1991), and which is still of interest to those who view strategy as practice or focus on the importance of microfoundations today (Vaara \& Whittington, 2012). If other civilizations had seen strategy as both planning and emergence, both big-picture and microfoundations, could not modern strategy thinkers view it this way too?

\section{Going Deeper: \\ Engaging With Original Rather Than Secondary Sources}

Although digitization has enabled great advances in management research, it stands to reason that more recent works are more likely to be digitized, and that those who learn to research in a digital age may be predisposed to look at what is available in this form at their desks rather than traveling further afield into original archives. Other writers in different fields have already published work theorizing that a reducing year range of citations may lead to a narrowing of scholarship and reduction in substantive innovation (Evans, 2008).

Looking beyond the ubiquity of the Internet may take researchers and educators to interesting places and offer new insights (Decker, 2013; Schwarzkopf, 2013). For example, tracking down hard copies of data created by long-established industry associations-data that does not exist online or in electronic form-has enabled some authors to think differently about the reasons why manufacturing clusters emerge and continue to evolve even after the economic reasons have declined (Sorenson \& Audia, 2000).

Similarly, looking at actual copies of Moody's Investment Magazine from 1911 (unavailable electronically) or the archive of the Stevens Institute in New Jersey (much of which is now available electronically) provides a very different view of the birth of 
management from that given in modern management textbooks. F. W. Taylor's work, so very prominent in the minds of management and business historians and other scholars as the point of origin (George, 1972; Wren, 1972; Wren \& Bedeion, 1994; Wren \& Hay, 1977), is something of an afterthought in these Moody's pages. Moody's, typical of newspapers of the time, focused for more on the legal and political setting for the "birth" of management as we know it. Indeed, even though we did not code for subject perspective in our sample of history articles anecdotally, we can say that most management and business historians appear to look from a conventional modernist management and business perspective. ${ }^{5}$ Hence, they focus on professions such as engineering and economics and see management science emerging due to organizations seeking to become more efficient or needing to quickly increase production to meet demand. However, legal and political histories show developments as much closer to the picture painted in the pages of Moody's, with the management movement riding the coattails of Roosevelt and Pinchot's short-lived "Conservation Movement" and gaining popularity only through Louis Brandeis' repackaging of the ideas of F.W. Taylor and others into something that he branded "Scientific Management" to win a high profile legal case in 1910-1911. The correspondence between Taylor and Brandeis is very insightful in this regard.

Looking from this unconventional perspective revealed to us that the first two books in management (if one chooses to believe that Scientific Management is where management studies proper began), the first published by Brondeis (1911; Scientific Management and the Railroads), the second by Taylor (1911), both begin by linking their theses to the idee du jour: conservation. Seeing conservation or sustainability as the origin of management might lead to interesting recalibrations around what it is that good management seeks to achieve.

Fruitful rethinking con also occur by considering what might be lost in translation. Recent work has begun to highlight how original work can be mis- or only partially translated when recast in English by Anglo writers. For example, what management students are shown to be Max Weber's contribution to

\footnotetext{
${ }^{5}$ It proved impossible to code for perspective quickly and reliably in any meaningful way. While we recognize that we do not, therefore, cover all of Tsui's (2007) and others' concerns in this regard, our aim, as stated earlier, was to do what we could to raise doubts about current conventions in management and business history so as to add to the debates about the dearth of new ideas as this relates to management education.
}

their field is a snippet seized upon by modern thinkers who saw bureaucracy as a wholly negative term and subsequently painted Weber as an outmoded bureaucracy booster-an interpretation partly enabled by the way that Talcott Parsons and others chose to translate some elements of Weber's work and not others and to emphasize certain interpretations above alternatives (Clegg, 2005; Mills, Weatherbee, Durepos, 2014), or to translate words in ways that created different meanings (e.g., Parsons translated Weber's use of herrschaft, which generally means "domination." as "leadership;" Cummings \& Bridgman, 2011). German speakers or German-based students might be able to reveal more about the times, life, and views of Weber, see how bureaucracy was both positively and negatively valued by Weber, and think about how his views might have provided safeguards against, and solutions for, the recent global financial crisis.

If innovation through diversity and cross-pollination is our goal, then it is important in our research to recognize that the language of an idea's origin may not necessarily translate universally and that we must, therefore, be dexterous so as to look in different ways and involve collaborators who can see from other linguistic perspectives. For example, we were involved in a discussion at a recent AoM conference with a senior management history professor and a young Chinese scholar. The professor described how in researching a new edition of a history of management he had sought contributions from a broader range of sites, but this had not borne fruit. Nobody in China, for example, offered anything new on the history of management in that country. His young counterpart suggested that if he had asked his Chinese sources for more on the history of "leadership" an easier translation for Chinese people to respond to positively he claimed, the professor would have got a lot more from his inquiries. Slevin and Terjesen (2011) provide a related analysis on how the word entrepreneurship has different meanings in different cultures.

We acknowledge that the study that spurs on our argument is limited. For reasons that we have explained, we have focused on simple dimensions that could be easily coded reliably across large samples: place and time. It might be argued that diversity could be analyzed by looking at disciplinary perspectives of the location that authors are based in, and we would encourage further studies that looked at these aspects. Although we have not directly linked greater historical diversity to greater innovation in management thought, we believe that the arguments linking homogeneity of 
perspective to a lack of innovation in the present should cause us to ponder how history may also play a role in limiting perspectives of what is relevant and possible in our field. In defense of these limitations, we have investigated history not to prove current interpretations wrong, to develop causal theories of what leads to innovation, or promote new truths, but to raise doubts about current norms so as to encouraging thinking otherwise or innovatively.

In response to our study, we have provided a set of examples of different possibilities for greater and more creative engagement with management and business history. However, these possibilities require specific intent from others now, because while there are some promising signs with respect to more interest in a range of new locations and periods, given current trends it will take a long time for percentages to grow to significant levels. We will need to make an effort to think differently (to "fill in the gaps" in Figure 9 and beyond) and create a more diverse archive that may inspire cross-pollination and creative thinking. This effort would, we argue, be well-rewarded. It could lead us to ask significant questions of what we consider worthy of attention in our field. Instead of unthinkingly seeing history as a legitimation of what we take management and business to be about now, we may rethink historical assumptions to "free thought from what it silently thinks, and so enable it to think differently" (Foucault, 1985: 11).

There are promising signs at the Academy with regard to broadening our views of management history and its contribution to thinking differently for the future (see, e.g., Hassard, 2012; Cooke \& Alcadipani, 2015; Rowlinson, Hassard, \& Decker, 2014; Usdiken \& Kipping, 2014; Wadhwani \& Bucheli, 2014; George, Corbishly, Khayesi, Haas, \& Tihanyi, 2016; Prieto \& Phipps, 2016). But we should build on this emerging research, by focusing our efforts on thinking about how we may inspire greater horizons for the next generation of management scholars by encouraging alternative historical precedents and perspectives for our field-perspectives that we can reflect upon when considering the present limits of our field and its future horizons.

\section{APPENDIX}

The table below shows the numbers and percentages of the articles surveyed from the six business management, medical, and architectural history journals published between 1950 and 2010 that could be coded for time of focus, place focus, and both time and place.

\begin{tabular}{|c|c|c|c|c|c|c|}
\hline & $\begin{array}{l}\text { Coded for } \\
\text { time/ Raw }\end{array}$ & $\begin{array}{l}\text { Coded for } \\
\text { time } \%\end{array}$ & $\begin{array}{l}\text { Coded for } \\
\text { place/ Raw }\end{array}$ & $\begin{array}{l}\text { Coded for } \\
\text { place } / \%\end{array}$ & $\begin{array}{l}\text { Coded for } \\
\text { both/ Raw }\end{array}$ & $\begin{array}{c}\text { Coded for } \\
\text { both/\% }\end{array}$ \\
\hline$B H$ & $724 / 859$ & $84.28 \%$ & 772 & $90 \%$ & 694 & $80.79 \%$ \\
\hline Total Coded Business & 1434 & $81.80 \%$ & 1529 & $87.22 \%$ & 1404 & $80.09 \%$ \\
\hline JHMAS & $580 / 602$ & $96.34 \%$ & 480 & $79.73 \%$ & 463 & $76.91 \%$ \\
\hline$B H M$ & $728 / 1554$ & $46.85 \%$ & 763 & $49.09 \%$ & 500 & $32.17 \%$ \\
\hline $\mathrm{CH}$ & $288 / 292$ & $98.63 \%$ & 259 & $88.70 \%$ & 257 & $88.01 \%$ \\
\hline Total Coded Architecture & 731 & $54.10 \%$ & 1153 & $85.34 \%$ & 659 & $48.77 \%$ \\
\hline
\end{tabular}

The table below shows the numbers and percentages of the articles surveyed from the two additional management history journals that are referred to in this article that could be coded for time of focus, for place focus, and for both time and place.

\begin{tabular}{|c|c|c|c|c|c|c|}
\hline & Coded for time/ Raw & Coded for time/ \% & Coded for place/ Raw & Coded for place $/ \%$ & Coded for both/Raw & Coded for both $\backslash \%$ \\
\hline$J M \& O H$ & $56 / 78$ & $71.79 \%$ & $50 / 78$ & $64.10 \%$ & $45 / 78$ & $57.69 \%$ \\
\hline
\end{tabular}




\section{REFERENCES}

Academy of Management. 2013. Announcement for Academy of Management Africa Conference, Johannesburg, South Africa, January 7-10, 2013. Downloaded from: http://meeting. aomonline.org/international/southafrica/.

Alvesson, M., \& Sandberg, J. 2011. Generating research questions through problematization. Academy of Management Review, 36(2): 247-271.

Alvesson, M., \& Sandberg, J. 2012. Has management studies lost its way? Ideas for more imaginative and innovative research. Journal of Management Studies, 50(1): 128-152.

Ansoff, H. I. 1991. Critique of Henry Mintzberg's 'The design school: Reconsidering the basic premises of strategic management'. Strategic Management Journal, 12(6): 449-461.

Baldwin, N. 1996. Edison: Inventing the century. New York: Hyperion.

Banta, M. 1993. Taylored lives: Narrative productions in the age of Taylor, Veblen, and Ford. Chicago: Chicago University Press.

Bartunek, J. M., Rynes, S. L., \& Ireland, R. D. 2006. What makes management research interesting, and why does it matter? Academy of Management Journal, 49(1): 9-15.

Bateman, T. S., \& Snell, S. S. 2009. Management: Leading \& collaborating in a competitive world, (8th ed.). Boston: McGraw-Hill.

Baumol, W. J. 1990. Entrepreneurship: Productive, unproductive, and destructive. Journal of Business Venturing, 11: 3-22.

Bayón, P. S. 2013. An approach to regulation on financial derivatives in the Spanish law. International Journal of Business and Social Research, 3(4): 132-138.

Belich, J. 1986. The New Zealand wars and the Victorian interpretation of racial conflict. Auckland: Auckland University Press.

Bettis, C. A., \& Prahalad, C. K. 1986. The dominant logic: A new linkage between diversity and performance. Strategic Management Journal, 7(6): 485-501.

Bettis, R. A., \& Prahalad, C. K. 1995. The dominant logic: Retrospective and extension. Strategic Management Journal, 16(1): 5-14.

Brandeis, L. D. 1911. Scientific management and the railroads. Engineering Magazine: New York.

Bruton, G. D., Fried, V. H., \& Manigart, S. 2005. Institutional influences on the worldwide expansion of venture capital. Entrepreneurship Theory and Practice, 29(6): 737-760.

Carey, R. 1863. Narrative of the late war in New Zealand. London: Bentley.

Chandler, A. D. 1959. The beginnings of 'big business' in Americon industry. Business History Review, 33(1): 1-31.

Chandler, A. D. 1977. The visible hand: The managerial revolution in American business. Cambridge, MA: Harvard University Press.

Chandler, A. D. 1990. Scale and scope: The dynamic of industrial capitalism. Cambridge, MA: Belknap Press of Harvard University Press.

Clark, T., \& Wright, M. 2009. So, farewell then... Reflections on editing the Journal of Management Studies. Journal of Management Studies, 46: 1-9.

Clegg, S. R. 2005. Puritans, visionaries and survivors. Organization Studies, 26(4): 527-545.
Cooke, B., \& Alcadipani, R. 2015. Towards a global history of management education: The case of the Ford Foundation and the Sao Paulo School of Business Administration. Academy of Management Learning \& Education, 14(4): 482-499.

Cornelissen, J., \& Floyd, S. W. 2009. The future ahead: Imagination, rigour and the advancement of management studies. Journal of Management Studies, 46: 11-15.

Cummings, S. 2002. Recreating strategy. London: Sage.

Cummings, S., \& Bridgman, T. 2011. The relevant past: Why the history of management should be critical for our future. Academy of Management Learning \& Education, 10(1): 77-93.

Decker, S. 2013. The silence of the archives: Business history, post colonialism, and archival ethnology. Management \& Organizational History, 8(2): 155-173.

Ellis, R. J. 2012. The development of the American Presidency. London: Routledge.

Ellis, P. D., \& Zhan, G. 2011. How international are international business journals? International Business Review, 20: 100-112.

Evans, J. A. 2008. Electronic publication and the narrowing of science and scholarship. Science, 321(5887): 395-399.

Foucault, M. 1985. The history of sexuality: Volume two - The use of pleasure. New York: Pantheon.

George, C. S. 1972. The history of management thought. Englewood Cliffs, NJ: Prentice-Hall.

Glassie, H. H. 1999. Material culture. Bloomington, IA: Indiana University Press.

Gordon, R., \& Howell, J. 1959. Higher education for business. New York: Columbia University Press.

Greif, A. 1993. Contract enforceability and economic institutions in early trade: The Maghribi traders' coalition. The American Economic Review, 83(3): 525-548.

Grey, C. 2010. Organizing studies: Publications, politics and polemic. Organization Studies, 31: 667-694.

Hassard, J. S. 2012. Rethinking the Hawthorne Studies: The Western Electric research in its social, political and historical context. Human Relations, 65(11): 1431-1461.

Jackson, S. E., Joshi, A., \& Erhardt, N. L. 2003. Recent research on team and organizational diversity: SWOT analysis and implications. Journal of Management, 29: 801-830.

Johansson, F. 2006. Medici effect: What you can learn from elephants and epidemics. Cambridge, MA: Harvard Business Press.

Jones, G., \& Khanna, T. 2006. Bringing history (back) into international business. Journal of International Business Studies, 37: 453-468.

Kanigel, R. 1997. The one best way: Frederick Winslow Taylor and the enigma of efficiency. New York: Viking.

Kearney, E., \& Gebert, D. 2009. Managing diversity and enhancing team outcomes: The promise of transformational leadership. The Journal of Applied Psychology, 94: 77-89.

Khurana, R. 2007. From higher aims to hired hands. The social transformation of American business schools and the unfulfilled promise of management as a profession. Princeton, NJ: Princeton University Press.

Kinicki, A., \& Williams, B. K. 2009. Management: A practical introduction, (4th ed.). Boston: McGraw-Hill. 
Kirkman, B., \& Law, K. 2005. International management research in AMJ: Our past, present, and future. Academy of Management Journal, 48(3): 377-386.

Koestler, A. 1970. The act of creation. London: Hutchinson.

Kuhn, T. 1970. The structure of scientific revolutions. Chicago: Chicago University Press.

Li, P. P. 2012. Toward an integrative framework of indigenous research: The geocentric implications of Yin-Yang balance. Asia Pacific Journal of Management, 29(4): 849-872.

Locke, E. 1982. Critique of Bramel and Friend. [Comment] The American Psychologist, 37: 858-859.

Mangaliso, M., \& Lewis, A. 2013. Strategic management research in developing nations: How relevant? In Academy of Management Proceedings, Downloaded from: http://meeting. aomonline.org/international/southafrica/.

Martin, R. 2009. The design of business. Boston, MA: Harvard Business Press.

McGrath, P. 2005. Thinking differently about knowledge intensive firms: Lessons from Medieval Irish Monasticism. Organization, 12(4): 549-566.

McGrath, P. 2007. Knowledge management in monastic communities of the Medieval Irish Celtic Church. Journal of Management History, 13(2): 211-233.

Mee, J. F. 1963. Management thought in a dynamic economy. New York: New York University Press.

Metz, I., \& Harzing, A. 2009. Gender diversity in editorial boards of management journals. Academy of Management Learning \& Education, 8(4): 540-557.

Meyer, K. E. 2006. Asian management research needs more selfconfidence. Asia Pacific Journal of Management, 23: 119-137.

Mills, A. J., Weatherbee, T. G., \& Durepos, G. 2014. Reassembling Weber to reveal the-past-as-history in management and organization studies. Organization, 21(2): 225-243.

Mintzberg, H. 1991. Learning 1, planning 0: Reply to Igor Ansoff. Strategic Management Journal, 12(6): 463-466.

Murrow, E. R. 1961. Broadcasted comments after President John F. Kennedy's inaugural address (20 January 1961). Quotation from https://en.wikiquote.org/wiki/Edward_R._Murrow.

Nattermann, P. M. 2000. Best practice does not equal best strategy. The McKinsey Quarterly, 2(May): 22-31.

Oliver, W. H. 1981. The Oxford history of New Zealand. Oxford: Oxford University Press.

Oswick, C., Fleming, P., \& Hanlon, G. 2011. From borrowing to blending: Rethinking the processes of organizational theory building. Academy of Management Review, 36(2): 318-337.

Parolo, P. D. B., Pan, R. K., Ghosh, R., Huberman, B. A., Kaski, K., \& Fortunato, S. 2015. Attention decay in science. Journal of Informetrics, 9(4): 734-745.

Payne, S. C., Youngcourt, S. S., \& Watrous, K. M. 2006. Portrayals of F.W. Taylor across textbooks. Journal of Management History, 12(4): 385-407.

Pierson, F. 1959. The education of American businessmen: A study of university-collegiate programs in business education. New York: McGraw-Hill.
Prieto, L. C., \& Phipps, S. T. 2016. Re-discovering Charles Clinton Spaulding's "The Administration of Big Business" Insight into early 20th century African-American management thought. Journal of Management History, 22(1): 73-90.

Polanyi, M. 1981. The creative imagination. In The concept of creativity in science and art: 91-108. Netherlands: Springer.

Prahalad, C. K., \& Ramaswamy, V. 2004. Co-creation experiences: The next practice in value creation. Journal of Interactive Marketing, 18(3): 5-14.

Robbins, S. P., Bergman, P., Stagg, I., \& Coulter, M. 2012. Management, (6th ed.). Sydney, NSW: Pearson Australia.

Rowlinson, M., Hassard, J., \& Decker, S. 2014. Research strategies for organizational history: A dialogue between organizational theory and historical theory. Academy of Management Review, 39(3): 250-274.

Rue, L. W., \& Byars, L. L. 2009. Management: Skills and applications, (13th ed.). Boston: McGraw-Hill.

Salvemini, G. 1939. Historian and scientist: An essay on the nature of history and the social. Boston, MA: Harvard University Press.

Sandberg, J., \& Tsoukas, H. 2011. Grasping the logic of practice: Theorizing through practical rationality. Academy of Management Review, 36(2): 338-360.

Schermerhorn, J. R., Davidson, P., Poole, D., Woods, P., Simon, A., \& McBarron, E. 2014. Management: Foundations and applications (2nd Asia-Pacific ed.). Milton, Queensland: Wiley.

Schwarzkopf, S. 2013. Why business historians need a constructive theory of the archive. Munich Personal RePEc Archive (MPRA) Paper, (46640), 1-12.

Shepherd, D. A., \& Sutcliffe, K. M. 2011. Inductive top-down theorizing: A source of new theories of organization. Academy of Management Review, 36(2): 361-380.

Shin, S. J., \& Zhou, J. 2007. When is educational specialization heterogeneity related to creativity in research and development teams? Transformational leadership as a moderator. The Journal of Applied Psychology, 92: 1709-1721.

Shrimpton, A. W., \& Mulgan, A. E. 1930. Maori \& Pakeha: A history of New Zealand. Auckland: Whitcombe \& Tombs.

Slevin, D. P., \& Terjesen, S. A. 2011. Entrepreneurial orientation: Reviewing three papers and implications for further theoretical and methodological development. Entrepreneurship Theory and Practice, 35(5): 973-987.

Smith, G. E. 2007. Management history and historical context: Potential benefits of its inclusion in the management curriculum. Academy of Management Learning \& Education, 6: 522-533.

Smith, W. K., \& Lewis, M. 2011. Toward a theory of paradox: A dynamic equilibrium model of organizing. Academy of Management Review, 36(2): 381-403.

Söderlund, J., \& Lenfle, S. 2013. Making project history: Revisiting the past, creating the future. International Journal of Project Management, 31(5): 653-662.

Sorenson, O., \& Audia, P. G. 2000. The social structure of entrepreneurial activity: Geographic concentration of footwear production in the United States, 1940-1989. American Journal of Sociology, 106(2): 424-462. 
Stambaugh, J. E., \& Trank, C. Q. 2010. Not so simple: Integrating new research into textbooks. Academy of Management Learning \& Education, 9(4): 663-681.

Suddaby, R., Hardy, C., \& Huy, Q. N. 2011. What are the new theories of organization. Academy of Management Review, 36(2): $236-246$.

Sundararajan, L. 2015. Indigenous psychology: Grounding science in culture, Why and how? Journal for the Theory of Social Behaviour, 45(1): 64-81.

Taylor, F. W. 1903. Shop management. New York: Harper \& Row.

Taylor, F. W. 1911. Principles of scientific management. New York: Harper.

Terjesen, S., Hessels, J., \& Li, D. 2013. Comparative international entrepreneurship: A review and research agenda. Journal of Management. Doi: 0149206313486259.

Tsoukas, H., \& Cummings, S. 1997. Marginalization and recovery: The emergence of Aristotelian themes in organization studies. Organization Studies, 18(4): 655-683.

Tsui, A. S. 2007. From homogenization to pluralism: International management research in the academy and beyond. Academy of Management Journal, 50(6): 1353-1364.

Usdiken, B., \& Kipping, M. 2014. History and organization studies: A long-term view. In M. Bucheli, \& R. D. Wadhwani (Eds.), Organizations in time: History, theory, methods: 33-55. Oxford: Oxford University Press.

Vaara, E., \& Whittington, R. 2012. Strategy as practice: Taking social practices seriously. The Academy of Management Annals, 6(1): 285-336.

Van Fleet, D. D., \& Wren, D. A. 2005. Teaching history in business schools: 1982-2003. Academy of Management Learning \& Education, 4(1): 44-56.

Vanderbroeck, P. 2012. Crises: Ancient and modern understanding an ancient Roman crisis can help us move beyond our own. Management \& Organizational History, 7(2): 113-131.

Wadhwani, R. D., \& Bucheli, M. 2014. The future of the past in Management and Organization Studies. In M. Bucheli, \&
R. D. Wadhwani (Eds.), Organizations in time: History, theory, methods: 3-30. Oxford: Oxford University Press.

Wagner-Tsukamoto, S. 2007. An institutional economic reconstruction of scientific management: On the lost theoretical logic of Taylorism. Academy of Management Review, 32(1): 105-117.

Welch, C., Piekkari, R., Plakoyiannaki, E., \& PaavilainenMöntymöki, E. 2011. Theorising from case studies: Towards a pluralist future for international business research. Journal of International Business Studies, 42(5): 740-762.

Whetten, D. A., Felin, T., \& King, B. 2009. The practice of theory borrowing in organizational studies. Current issues and future directions. Journal of Management, 35: 537-563.

White, M., \& Gribbin, J. 2005. Einstein: A life in science. New York: Free Press.

Williams, K. Y., \& O’Reilly, C. A. 1998. Demography and diversity in organizations: A review of 40 years of research. In B. M. Staw \& R. Sutton (Eds.), Research in organizational behaviour, 20: 77-140. Greenwich, CT: JAI.

Wrege, C., \& Perroni, A. 1974. Taylor's pig tale: A historical analysis of Frederick W. Taylor's pig-iron experiments. Academy of Management Journal, 17: 6-27.

Wren, D. A. 1972. The evolution of management thought. New York: Ronald Press.

Wren, D. 1979. The evolution of management thought, (2nd ed.). New York: John Wiley \& Sons.

Wren, D. 1994. The evolution of management thought, (4th ed.). New York: John Wiley \& Sons.

Wren, D. A. 2000. Medieval or modern? A scholastic's view of business ethics, circa 1430. Journal of Business Ethics, 28(2): 109-119.

Wren, D. 2005. The history of management thought, (5th ed.). New York: John Wiley \& Sons.

Wren, D. A., \& Bedeian, A. G. 1994. The evolution of management thought. New York: John Wiley.

Wren, D. A., \& Hay, R. D. 1977. Management historians and business historians: Differing perceptions of pioneer contributors. Academy of Management Journal, 20(3): 470-476.

Stephen Cummings is a professor of management at Victoria Business School, Wellington, New Zealand. Cummings received his doctorate from the University of Worwick. His research interests include examining how conventional historical assumptions limit innovation in management and organization studies, and creative approaches to the development and communication of strategy.

Todd Bridgman is a senior lecturer in the School of Management at Victoria Business School, Wellington, New Zealand. Bridgman received his doctorate from the University of Cambridge. His research is focused on critical approaches to management learning and education, including representations of management and organizational history. 